Modified apparatus and techniques were, of course, required : (a) because of the small scale of the operations; (b) on account of the volatility of the active intermediates and final product.

It is considered that the above direct method of preparing radioactive diisopropyl fluorophosphonate possesses advantages compared with the method of B. Witten and J. I. Miller, which starts with radioactive potassium dihydrogen phosphate ${ }^{3}$.

We are grateful to the Chief Scientist, Ministry of Supply, for permission to publish this communication, and we wish to thank Dr. A. G. Maddock for his valuable advice in connexion with the investigation.

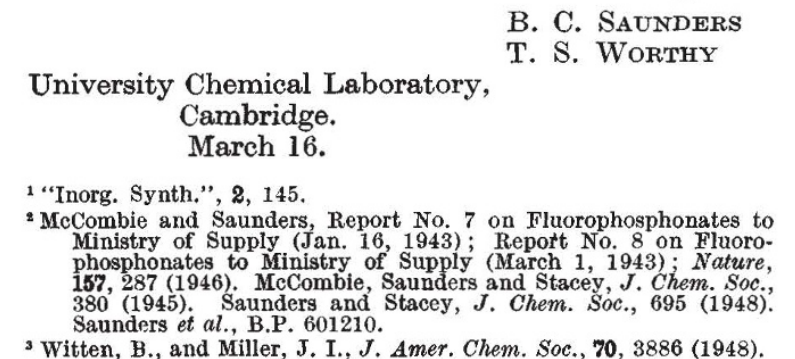

\section{Extraction of Pantothenic Acid from Natural Materials}

ThE usual method for the extraction of pantothenic acid from natural materials preparatory to microbiological assay consists of heating at about neutral $p \mathrm{H}$, followed by incubation with enzymes at $p H$ 4-5 for twenty-four hours or longer ${ }^{1,2}$.

In certain cases it is possible to increase the amounts of pantothenic acid extracted by $200-400$ per cent by cold alkali treatment prior to enzyme treatment. The highest values for malt observed have been obtained by the following technique: steam $1 \mathrm{gm}$. of material for $30 \mathrm{~min}$. in $25 \mathrm{ml}$. of $0 \cdot 1 \mathrm{M}$ sodium acetate, cool, add $5 \mathrm{ml}$. of $10 \mathrm{~N}$ sodium hydroxide, allow to stand at room temperature for $5 \mathrm{~min}$., add sufficient sulphuric acid to make slightly acid, adjust to $p \mathrm{H} 4.5$, add $0.5 \mathrm{gm}$. of papain and $0.5 \mathrm{gm}$. of takadiastase of known pantothenic acid content, incubate for three days at $37^{\circ} \mathrm{C}$. under toluene, filter and make up to a known volume at $p H \mathbf{H} \cdot 8$.

Using this procedure, followed by acidimetric Lactobacillus arabinosus microbiological assay, the measurable pantothenic acid content of a sample of malt was increased to $13 \mu \mathrm{gm}$. $/ \mathrm{gm}$. from a value of $5 \mu \mathrm{gm} . / \mathrm{gm}$. liberated by the normal steaming and enzyme treatment. Fat extraction with petroleum ether after enzyme treatment did not significantly affect the results. In the case of malt extract, a value of $7 \mu \mathrm{gm}$. $/ \mathrm{gm}$. obtained by the usual enzyme treatment was increased to $24 \mu \mathrm{gm} . / \mathrm{gm}$. by soda treatment only. Further treatment with enzymes did not significantly increase this figure. The same increase in apparent pantothenic acid content on treatment with soda was obtained when Saccharomyces carls. bergensis " 4228 " was used as the test organism.

Malt wort behaved in a similar way to malt and malt extract, whereas animal muscle, yeast and molasses were not greatly affected by the alkali treatment. It is suggested that in plant products the pantothenic acid is present in a different form from that which occurs in animal materials and microorganisms. The exceptional response of molasses may be due to the rather drastic purification process to which it has been subjected.

A full account of this work will be published elsewhere.

\section{J. S. HARRISON}

Research and Development Department, Distillers Company, Ltd., Epsom.

Nov. 26.

${ }^{1}$ Cheldelin, V. H., Eppright, M. A., Snell, E. E. and Guirard, B. M., Univ. Texas Pub., No. 4237, 15 (1942).

${ }^{2}$ Neal, A. L., and Strong, F. M., Indust. and Eng. Chem., Anal. Ed., 15, 654 (1943).

\section{Reactivity of the Sulphur Linkage in Wool}

THE view that disulphide bond breakdown in the cuticle of wool fibres is responsible for their resistance to felting after treatment with chlorine, sodium hydroxide and sulphuryl chloride has been confirmed ${ }^{1}$ by showing that wool treated with $0.1 N^{\prime}$ sodium hydroxide solution for $10-24 \mathrm{hr}$. at $22 \cdot 2^{\circ} \mathrm{C}$. is more resistant to these reagents than untreated wool. Treatment with sodium hydroxide was believed to convert a high proportion of the disulphide bonds into the more resistant lanthionine and $-\mathrm{CH}=\mathrm{N}-$ cross-linkages; but since there is now doubt ${ }^{2}$ about the existence of the latter in alkali-treated wool, it seemed advisable to repeat the experiments with wool which had been treated with potassium cyanide. Cuthbertson and Phillips have shown ${ }^{2}$ that most of the cystine in loose wool is converted into lanthionine by treatment with a 1 per cent solution of potassium cyanide for only $30 \mathrm{~min}$. at $66^{\circ} \mathrm{C}$. :

$$
R-\mathrm{S} \longrightarrow \mathrm{S}-R \stackrel{\mathrm{KCN}}{\longrightarrow} R . \mathrm{SK}+R . \mathrm{SCN} \rightarrow \underset{R \longrightarrow \mathrm{S}-R+\mathrm{KCNS} .}{\longrightarrow}
$$

Two $2 \cdot 5$-gm. patterns of an all-wool flannel were therefore immersed in 500 c.c. of a $0.1 M$ solution of potassium cyanide for $3 \mathrm{hr}$. at $65^{\circ} \mathrm{C}$. After being washed in running water overnight, the patterns were squeezed and conditioned in a room at 65 per cent humidity and $22 \cdot 2^{\circ} \mathrm{C}$. One of the patterns was then treated with 4 per cent of chlorine (on the weight of the wool) in a buffer solution at $p H$ 4. After excess chlorine had been removed with a 0.5 per cent solu. tion of sodium bisulphite, the fabric was neutralized with 0.5 per cent sodium bicarbonate solution and washed in running water overnight. An untreated pattern of flannel was chlorinated in the same way, and the three patterns, with a sample of untreated flannel, were milled together by hand in 5 per cent soap solution.

The resulting shrinkages are given in the accom. panying table, which includes corresponding data for 2.5-gm. conditioned patterns treated with either 100 c.c. of a 0.75 per cent solution of potassium hydroxide in 97 per cent alcohol for 35 minutes at $25^{\circ} \mathrm{C}$, , or with 100 c.c. of a 2.5 per cent $(\mathrm{v} / \mathrm{v})$ solution of sulphuryl chloride in carbon tetrachloride for $1 \mathrm{hr}$. at $22 \cdot 2^{\circ} \mathrm{C}$. In the second case, 1 per cent of oleic acid was first added to the patterns from alcoholic solution in order to promote reaction with sulphuryl chloride $^{3}$. The table also includes data obtained in a parallel series of experiments with patterns which had been treated with $0.1 M$ potassium cyanide solution for $24 \mathrm{hr}$. at $65^{\circ} \mathrm{C}$. In all cases, the shrinkages are based on the wetted-out areas of the patterns immediately before milling. 